Uniwersytet Warmińsko-Mazurski w Olsztynie

Wydział Nauk Społecznych

Katedra Wczesnej Edukacji

tel. +48604275848

e-mail: xzbyszek@me.com

ORCID ID: https://orcid.org/0000-0002-6543-0875

\title{
Культурно-образовательные аспекты концертной деятельности в рамках польско-русско-белорусского сотрудничества
}

Ключевые слова: музыка вокальная, бас, сольный концерт, образование, международное сотрудничество.

\section{1. Вступление}

Музыкальные педагоги и психологи сегодня уверяют в необходимости творческого общения с музыкой, направленного на развитие личности на основе когнитивной, эмоциональной, культурно-обрядовой и игровой деятельности. Действительно, музыка сопровождает людей в различных жизненных ситуациях. Затрагивая все виды эмоций и наш интеллектуальный опыт, следует отметить, что музыка обогащает нашу жизнь. Разнообразные модели деятельности в музыкальном образовании на основе социального партнерства позволяют координировать процесс культурного воспитания в рамках единой образовательной среды.

Автор данной статьи в качестве музыканта-исполнителя (бас, бассо-профундо) дает 30-40 вокальных концертов в год, сотрудничает с многочисленными организациями и учреждениями и в связи с этим может описать модель сотрудничества в музыкальном образовании как 
конструктивное взаимодействие, направленное на решение конкретных задач. Партнерство с образовательными организациями в Польше, России и Белоруссии в рамках организованных автором тематических концертов для студентов колледжей и университетов позволяет приблизить большое количество заинтересованных профессионалов-музыкантов для оптимизации образовательного процесса, приближения музыки к слушателю.

Как известно, музыкальные концерты часто готовят в сотрудничестве, пишут различные типы сценариев. Рабочая группа каждого музыкального проекта разрабатывает программы, выбирает соответствующих сопровождающих музыкантов, готовит вступительное слово и выстраивает драматургию музыкального материала концерта. Кстати сказать автор настоящей статьи представленную выше предварительную подготовку данного концерта довольно часто проводит самостоятельно. Тщательная разработка оригинального сценария, отражающего идею проводимого мероприятия, обычно направлена на знакомство студентов с историей музыки, культуры, литературы, мировой истории и истории стран, из которых происходят композиторы или исполнители. Цель данного вида деятельности, таким образом, включает в себя преподавание и обучение музыке детей и молодежи, а также предоставление возможности приобщения к высокой музыкальной культуре людей так называемого «третьего возраста», являющихся также студентами в современных вузах.

По мысли В.А. Захер, следует отличать понимание концептов музыкального образования и музыкального воспитания: "Музыкальное образование является плановым и структурированным процессом музыкального образования, ориентированным на позитивные изменения в области навыков и умений музыки, позитивного и зрелого отношения к музыке и музыкальной культуре. В то время воспитание посредством музыки относится к таким явлениям, как развитие музыкальных и общих умственных и физических способностей студентов, формирование поведенческих навыков, социализации, формирование личностных качеств и темперамента (с особым акцентом на положительные эмоции), профилактику и лечение через музыкальное обучение расстройств поведения, а также профилактику и лечение задержки психического и физического развития" [Sacher 2012, 161-162].

Кроме того, В. А. Захер также отмечает, что “музыкальное образование и воспитание в текущих задачах эстетического воспитания включает в себя два дополняющих друг друга и тесно связанных с собой образовательных процесса, то есть музыкальное образование и образо- 
вание через музыку, как она была сформулирована Герберт Рид в отношении эстетического воспитания, то есть образования через искусство. Эти процессы углубления сферы интеллектуального, нравственного и социального стимулирования выражаются в творчестве отдельных лиц, обогащают личность и продвигают смыслы музыкального искусства в область оценки и чувств, но наиболее важный аспект воздействия музыки заключается в том, чтобы вызвать изменения в блоке, который будет способствовать улучшению функционирования как личных, так и социальных качеств" [Sacher 2012, 164]. Именно эти аспекты музыкального образования и воспитания студентов учитывал автор предложенной модели музыкального концерта.

\section{2. Биографический очерк. Основы музыкального и педагогического опыта автора}

Первое музыкальное образование автор данной статьи получил на музыкальных курсах для любителей (Społeczne Ognisko Muzyczne - Начальная музыкальная школа) в своем родном городе Венгожеве. После получения аттестата зрелости (1987) изучал философию и теологию в Высшей духовной семинарии Hosianum в Ольштыне в годах 1988-1994. После посвящения в духовный сан начал работать в Ольштынке викарием и учителем религии в Школе профессионального обучения в том же городе. Автор в течение шести лет (1994-2000) руководил детским хором Vox Cordis. На основании этого опыта мог определить основные методы работы с детьми. Хор получил множество наград на различных фестивалях религиозных песен, в том числе, в июне 2000 года - в Швейцарии. Музыкально-педагогическая работа с детским хором в Ольштынке стала мотивацией для проведения дальнейших творческих поисков и исследований [Stępniak 2003, 28-55]. В годах 1997-2000 автор изучал педагогику музыки в Институте музыки в Варминско-мазурском университете в Ольштыне. В то же время автор изучал постановку голоса в Музыкальной академии им. Ф. Нововейского в Быдгощи и Национальном центре культуры в Варшаве.

В 2006-2009 годах был приходским ксендзом в Рамсове, расположенном в 25 км от города Ольштын. Будучи инициатором и первым художественным руководителем Летних концертов вокальной музыки Varmia gaudet et cantat получил дальнейшую мотивацию и стал развиваться как певец-солист, а также как педагог (проведение концертов 
и бесед о музыке). В это время интенсивно развивается концертная деятельность в стране и за рубежом, что стало стимулом для дальнейшего обучения - на Факультете вокально-актерском Музыкальной академии им. Ф. Нововейского в Быдгощи, которую окончил в 2012 году, исполняя три вокальных концерта (преобладали произведения из эпохи Барокко) и защищая магистерскую диссертацию под заглавием "Концерт Deus in nomine Tuо Марцина Мельчевского в контексте анализа произведения, риторики музыки и исполнительских проблем" (на польском языке: "Koncert Deus in nomine Tuo Marcina Mielczewskiego w kontekście analizy dzieła, retoryki muzycznej oraz problemów wykonawczych").

Итогом исследований в области музыки стали: докторская диссертация и теоретический курс в секции теоретического и прикладного музыковедения в Университете кардинала Стефана Вышинского в Варшаве (2000-2004). В октябре 2011 года автор защитил докторскую диссертацию на Факультете социальных и исторических наук в Университете кардинала Стефана Вышинского в Варшаве. Тема диссертации: "Исследование репертуара выбранных польских академических хоров в течение двух десятилетий с 1980 по 2000 год" (на польском языке: "Studium repertuaru wybranych polskich chórów akademickich w dwudziestoleciu 1980-2000").

Преподавательская деятельность автора началась с 2004 г., с работы в качестве преподавателя в различных университетах в Польше: в Университете Адама Мицкевича в Познани (Poznań), в Последипломной студии постановки голоса Музыкальной академии им. Ф. Нововейского в Быдгощи, в Филологически-историческом институте в г. Млаве (Mława), Государственном профессиональном училище в Цеханове (Ciechanów) (2006-2008), в Архиепископской школе музыкантов католического костела (2007-2012) и других. Кроме того сотрудничал с Варминско-мазурским центром образования учителей в Ольштыне (обучение учителей постановке и гигиене голоса). Однако первым местом работы (с января 2006 года) является Варминско-мазурский университет (UWM) в Ольштыне, с марта 2014 года (до сих пор) как кандидат наук в Кафедре дошкольного образования на Факультете социальных наук этого университета. Автор (и одновременно певец) преподает постановку голоса, гигиену голоса, историю музыки, театра и драмы для студентов направления дошкольного обучения.

Авторские проекты: художественно-педагогическое руководство вокальных ансамблей и хоров (детский хор в Ольштынке, хор взрослых в Рамсове, Мужской вокальный ансамбль в Ольштыне, работа со студентами разных вузов). В последние годы, автор проводит вокальные 
концерты в стране и за рубежом (Беларусь, Чехия, Германия, Россия (в Сибири), Швейцария).

В качестве консультирующего художника-педагога, автор дает уроки вокала для солистов и вокальных коллективов. Опыт в проведении музыкальных концертов позволяет совмещать работу художника и педагога, ведущего концерты, а также дает возможность представлять широкой аудитории историко-филологический и музыковедческий контекст композиции.

\section{3. Характеристика отдельных концертов для определенных возрастных групп слушателей, организованных в сотрудничестве со школами и вузами}

Авторские вокальные концерты в Польше и за рубежом проводятся в количестве от 30 до 40 концертов в год. С августа 2007 года до сих пор проведено более 170 вокальных концертов. Концерты часто организуются для конкретных групп слушателей: от младших школьников, учащихся средних школ до студентов вузов и пожилых людей.

Интересным опытом сотрудничества был ряд концертов, организованных в рамках академической стажировки в Гродненском государственном университете им. Янки Купалы в сотрудничестве с Гуманитарным колледжем в Гродно в октябре 2013 года. Автор был организатором четырех сольных концертов, три из которых имели место в начальных школах. Успешное сотрудничество с пианистками из Гродно, И. Граховской и Н. Радзинской, обеспечило высокую оценку этих концертов слушателями, которыми были дети в возрасте с 7 до 15 лет. Хотя их возраст заранее был определен заведующими школами, оказалось, что на концерт пришли дети моложе ранее установленного возраста. В такой ситуации пришлось гибко переключаться на ожидания слушателей. K тому же учесть перцепционные способности молодых слушателей.

Слушателями второй возрастной группы были старшеклассники, в основном молодые люди в возрасте 15-18 лет. Концерты проходили в Гуманитарном колледже и Музыкальном колледже в Гродно. Соблюдение все принципов организации концерта, предвиденных для этой возрастной группы, обеспечило успех.

В организации вокальных концертов мы также сотрудничаем с ассоциациями университетов так называемого «третьего возраста» (Uniwersytet Trzeciego Wieku), которые существуют в Варминско-мазур- 
ском университете в Ольштыне, в городах Кентжин, Венгожево, Нове Място Любавске, Дзалдово, и с Ассоциацией выпускников в городе Ольштыне. В университетах «третьего возраста» пенсионеры углубляют свои знания в области иностранных языков, информатики и компьютерных навыков, а также организуют хоры, слушают лекции профессоров и преподавателей, приглашаемых из университетов.

В связи с этим лекции по истории музыки и упражнения по постановке голоса, проведенные автором настоящей статьи для взрослых слушателей, стали стимулом для организации научных и концертных вокальных мероприятий разными ассоциациями. Успех такого партнерства заключается в сотрудничестве всех культурных организаций в рамках единой образовательной среды, направленной на решение актуальных социальных и культурных нужд людей пенсионного возраста.

Кроме того, автора приглашают принять участие в организации культурно-массовых мероприятий, которые проводятся в культурных центрах, на музыкальных фестивалях, в театрах, концертных залах, а также в католических приходах. В названной выше деятельности учитываются разные возрастные группы: школьники, молодежь, взрослые, в том числе пожилые, люди.

Делясь конкретным опытом по организации концертов в рамках партнерства и международного сотрудничества, необходимо подчеркнуть, что важной проблемой является тщательный подбор репертуара и вступительного слова, которые должны быть адаптированы к возрасту аудитории. Кроме того, необходимо разработать порядок представления произведений, исполняемых во время концертов. Он должен быть построен таким образом, чтобы постоянно привлекать внимание слушателей. Драматургия концерта должна развиваться в логическом порядке, чтобы развернуть все смыслы музыкального материала от зачина к кульминации и финалу. В результате этого слушателю не скучно будет слушать концерт. Весь концерт должен, следовательно, не утомлять аудиторию, независимо от возраста, держать в напряжении на протяжении всего выступления. Важно в этом контексте, чтобы первая песня строила атмосферу концерта, а последняя - суммировала все эстетическое восприятие. Первое произведение не может быть слишком сложным (с точки зрения реализации и восприятия), в то же время как последнее должно позволить развить позитивное чувство слушателя [Stępniak 2012, 89-102]. То же самое касается подготовки информации о репертуаре. Слово о музыке должно быть приспособлено к возрасту слушателей. Как певец и ведущий концерты автор статьи 
полагает, что лучше дать меньше информации на тему исполняемых произведений и композиторов, но стимулировать интерес слушателей к музыке, к собственным поискам и размышлениям. Кроме того, не стоит никого особенно убеждать, что петь и вместе с тем вести концерт это безусловно нелегкая задача, в силу того, что надо поочередно говорить и петь.

\section{4. Образовательные аспекты отдельных концертов}

Концерты классической музыки, направленные на детскую аудиторию, по мнению В. А. Захер, должны характеризоваться высоким уровнем исполнительской культуры и тщательным подбором репертуара. "На начальном этапе - это ограниченное восприятие и слушателю необходимо научиться ассоциироваться под музыку - за это отвечает его тайна, связанные с опытом чувства и эстетические формы собственного отношения к этому искусству" [Sacher 2012, 157]. Частые контакты с музыкой очень важны для детей и подростков, потому что развивают их восприятие, эмоциональную и художественную чувствительность. В связи с тем следует отметить, что концерты для этих возрастных групп должны отличаться специфическим способом организации музыкальной программы. В программу стоит включить комментарии из области композиции и стиля исторической эпохи, к тому же дополняемые упоминаниями о самых интересных событиях из жизни и творчества композитора. Эти процедуры должны быть разработаны, чтобы пробудить интерес и сосредоточить внимание на процессе восприятия музыки, оставить положительный эмоциональный след в молодых слушателях [Sacher 2012, 157-158].

Представленная выше стратегия была использована также при подготовке концертов для детей младшего школьного возраста, которые состоялись в Гродно 23-25 октября 2013 г. Цикл концертов был озаглавлен $O$ любви в опере, польской песне и русском романсе. Первоначально программа концерта включала тринадцать произведений, в том числе пять оперных арий (арии Вольфганга Амадея Моцарта: ария Лепорелло Notte e giorno faticar из оперы Дон Джованни и ария Зарастро O Isis und Osiris из оперы Волшебная флейта, ария кардинала Брони Se oppressi ognor из оперы La Luive (Еврейка), песня Варега О скальл грозные из оперы Садко Н. Римского-Корсакова и ария Сколубы Cтаринные часыл из оперы Cтрашный замок С. Монюшко, три песни Монюшко (Солтьлс, Дед и баба, Песнь моряков) и пять русских 
романсов. Оказалось, что программа концерта для большинства слушателей была слишком амбициозной. Надо было перед началом концерта исключить некоторые из песен и больше времени предназначить для беседы о музыке. В итоге концерт заинтересовал большое количество детей, а их интерес поддерживали вопросы о некоторых фактах из истории музыки.

Стоит отметить несколько тематических концертов, которые в 2016 г. были даны для студентов колледжей в Гродно. Первый (21 июня) был назван Гори, гори моя звезда - между религиозной и мирской музыкой. В главных ролях выступили: Н.В. Парфилова сопрано, 3. Стемпняк - бас, И.А. Граховская - фортепиано. Концерт состоял из двух частей: религиозных и мирских произведений. Дал он возможность показать молодым людям культурную близость двух народов: поляков и белорусов. Первая часть, которую составляли произведения С. Монюшко, дала возможность слушателям воспринять музыкальные формы композитора, а также латинские молитвы в литургии католической церкви. Следует добавить, что произведения Монюшко созданы на перекрестке культур - польской, белорусской и литовской. Вторая часть концерта была близка к менталитету белорусского народа, представляла шесть русских романсов в интерпретации польки из Гродно и поляка из Ольштына.

Очередной концерт, организованный для молодых людей в Гуманитарном колледже г. Гродно в октябре 2016 года, был озаглавлен Не пробуждай воспоминаний. Выступали: Збигнев Стемпняк - бас и И.А. Граховская - фортепиано. В программу концерт вошли песни на польском и русском языках. В первой части исполнялись песни С. Монюшко и современного польского композитора П. Лукашевского. Этот материал дал возможность вновь приблизить аудитории композиции Монюшко, познакомить с музыкой Лукашевского, а также с творчеством известных польских поэтов и писателей, таких как А. Мицкевич, И.И. Крашевски и Ч. Милош. Вторую часть концерта составляли классические русские романсы хорошо известные белорусским молодым слушателям, и на самом деле подробные комментарии были не нужны.

Следующей группой слушателей, для которых были организованы сольные концерты, являются люди - студенты университетов «третьего возраста». Это определенная группа людей, образованных ценителей музыки и литературы. В течение одиннадцати лет концертной деятельности автор дал более 30 сольных концертов для слушателей этой возрастной группы. Они были организованы такими учреждени- 
ями как: Институт христианской культуры им. Яна Павла II в Ольштыне, Ассоциация выпускников Варминьско-мазурского университета в Ольштыне, Варминско-мазурский университет «третьего возраста» в Ольштыне, Университет «третьего возраста» в Дялдове или Общество друзей Земли Вильнюса в Ольштыне.

На основании заглавий концертов можно приблизительно оценить их культурную и образовательную стоимость. Следует привести, по крайней мере, некоторые названия концертов:

- Wyśpiewać miłość - Kto śpiewa, dwa razy sie modli... (Cnеть любовь - Kто поет, молится дваждын...),

- Ze śpiewnika domowego - pieśni Stanisława Moniuszki (Из домашнего песенника - песни С. Монюшко),

- W oczekiwaniu na Boże Narodzenie - koncert pieśni religijnych i kolęd (B преддверии Рождества - концерт религиозных песен и колядок),

- W barokowym nastroju (В барочном настроении),

- Polskie - najpiękniejsze - koncert muzyki kompozytorów polskich (Польские - самье красивые - концерт музыки польских композиторов),

- Концерт патриотических песен,

- Muzyka zza осеапu - koncert pieśni musicalowych ( Музыка из-за океана- концерт песен из музиклов),

- Zatrzymaj się na chwile... - pieśni religijne kompozytorów różnych epok (Остановитесь на мгновение... - религиозные песни композиторов разных эпох),

- Pieśni pisane cyrylica - koncert pieśni i romansów rosyjskich (Песни кириллицей написанные - концерт русских песен и романсов),

- Swieć, świeć, gwiazdo moja - recital mieszczańskich romansów rosyjskich (Гори, гори, моя звезда-концерт русских романсов),

- Budzić wspomnienia minionych dni - recital wokalny z okazji zjazdu absolwentów Uniwersytetu Warmińsko-Mazurskiego w Olsztynie (Проснувшиеся воспоминания о давно минувших днях - вокальный концерт по случаю встречи выпускников Варминьско-мазурского университета в Ольштыне),

- Swiat opery - arie ze znanych oper (Mup onepbr),

- Od Zieleńskiego do Eukaszewskiego - koncert muzyki polskiej (Om 3eленского до Лукашевкого - концерт польской музыки),

- Na granicy ze Wschodem - znane pieśni polskie i rosyjskie w polsko-białoruskiej interpretacji (На граниче с Востоком - известные польские и русские песни в польско-белорусской интерпретации). 
Интересным опытом музыкального партнерства в карьере автора, как певца, был концерт под заглавием $O m$ любви $\kappa$ Богу, по любовь $\kappa$ людям, который состоялся в кафедральном соборе в Иркутске, в начале октября 2016 года. Исполнителями были: З. Стемпняк - бас, бассо-профундо и Д. Григоруце - орган, фортепиано. Жители Иркутска имели возможность познакомиться с европейской музыкой, в том числе с сочинениями С. Монюшко и П. Лукашевского. Программа включала в себя священную и мирскую музыку разных эпох. Концерт поддержал соборный органист Д. Григоруце, который приготовил информацию о композиторах и авторах песен, взяв на себя перевод текстов на русский язык, что, несомненно, значительно облегчило восприятие барочной музыки.

Автор статьи хотел бы обратить внимание на еще один концертный проект. Концерт под названием Между сакрум и профанум - обучайте музыкой! был дан в рамках Первой международной научной конференции «Человек - искусство - образование» 11 июня 2014 года. Программа состоялась из девяти религиозных и мирских произведений от барокко до современности. Каждое из них дало возможность определить образовательный характер вокального исполнения по отношению к конкретным областям жизни и науки. Например, вокальный концерт Deus in nomine Tuo M. Мельчевского дал возможность приблизить слушателям библейскую теологию и историю Псалма 53 (Боже, храни меня в имени...). Песня Ave Maria В. Вавилова дала возможность представить случай мистификации музыки. Возможность познакомиться с польской литературой дали песни: $W$ mojej Ojczyźnie П. Лукашевского на слова Ч. Милоша, Znasz-li ten kraj С. Монюшко на слова Mignon Й. Гете в переводе А. Мицкевича.

\section{5. Заключение}

Анализируя образовательный аспект концертной деятельности, особенно по отношению к конкретным возрастным группам слушателей, стоит подчеркнуть ее музыкотерапевтические свойства. На это явление обращает внимание Мариоля Коковска: "Muzyka, jej znaczenie i natura, jest formą sztuki zdolną do wyrażania symbolu i komunikowania pozamuzycznych emocji. (...) Umiejscowienie emocji na zewnątrz lub ich wewnętrzne poczucie, podobnie jak rozróżnianie stanu emocji odczuwanych $\mathrm{w}$ odpowiedzi na muzykę wobec stanu postrzegania emocji, ukazuje perspektywę psychologii muzyki. W obszar dialogu wpisu- 
je się dziedzina muzykoterapii, która aspekt emocji włącza..." [Kokowska 2015, 169-170].

Передача этих "внемузыкальных эмоций", в психологическом и педагогическом аспекте имеет глубокий отклик в эдукационной плоскости перцепции вокальных произведений, что автор в этой статье хотел показать.

Стоит отметить, что одним из важных аспектов проведения концертов в рамках социокультурного проекта, учитывающего музыкальное образование детей и молодых людей, является непосредственный контакт с исполнителями и привлечение к сотрудничеству заинтересованные культурно-социальные структуры (театры, библиотеки, образовательные центры, школы, вузы, меценатов от бизнеса).

Таким образом, можно заключить, что музыкальное образование и воспитание должно осуществляться систематически. Процесс приобщения личности к музыке длится долго. Он начинается с рождения и продолжается в течение всей жизни человека. Кроме того, участие детей и молодежи в концертах классической музыки, в том числе вокальных концертах, должно быть формой дополнительного культурного образования в рамках единой образовательной среды. В Польше нет статистических данных, касающихся числа детей и молодых людей, посещающих этот тип концертов. Однако эта форма обучения очень часто используется. Пока концерты как вид социального и культурного партнерства не получают широкого распространения. Концерты проходят в основном в крупных городах, а для участия детей и молодежи из малых городов требуются значительные материальные расходы. В этой связи многие музыкальные педагоги, музыканты, в том числе автор этой статьи, предлагают к реализации музыкальные проекты для общин малых городов, с тем чтобы приобщить население к музыкальному искусству. Стоило бы, чтобы городские и коммерческие структуры активнее участвовали в решении проблем приобщения детей и молодежи к музыке. Для того надо расширять формы меценатства и спонсорства музыкальных мероприятий.

\section{Литература}

Kokowska M., 2015, Spoleczny i emocjonalny aspekt komunikacji muzycznej w muzykoterapii, [w:] Muzyka w dialogu z edukacja. Wybrane konteksty aktywności i edukacji muzycznej, red. E. Kochanowska, R. Majzner, Kraków, s. 161-182.

Sacher W.A., 2012, Pedagogika muzyki. Teoretyczne podstawy kształcenia muzycznego, Kraków. 
Stępniak Z., 2003, Olsztynek - miasto sercem śpiewajace, Olsztynek.

Stępniak Z., 2012, Wybrane polskie chóry akademickie w dwudziestoleciu 19802000. Repertuar - konkursy - wykonania, Lublin.

\section{CULTURAL AND EDUCATIONAL ASPECTS OF CONCERT-GIVING ACTIVITY AS PART OF THE POLISH-RUSSIAN-BELARUSSIAN CO-OPERATION}

S U M M A R Y

The author of the present paper is a performing musician (a basso profondo singer), who gives 30-40 recitals per year and co-operates with many cultural organizations and institutions (including the ones in Grodno, Kaliningrad, Irkutsk and Novosibirsk). He usually prepares his concerts himself at all stages of organization, from writing projects, developing programs, selecting accompanying musicians and formulating opening words, to being a compère of the whole event. This is done with a special purpose in mind, that is to introduce the audience to the music, culture, literature and history of the home country of the composers or authors of lyrics of particular pieces. Therefore, the carefelly prepared concerts are to serve an educational role (especially as regards young audience) and to fulfill certain pedagogical tasks. 